\title{
Impact of a clinical pharmacist on ultrasound-guided venous thromboembolism screening in hospitalized COVID-19 patients: a pilot prospective study
}

Laura Gillespie', Rashid Z. Khan², John E. Stillson³, Connor M. Bunch³, Faisal Salim Shariff', Jacob Speybroeck, Anne Grisoli ${ }^{3}$, Meredith Wierman Schmidt ${ }^{4}$, Htay Phyu ${ }^{4}$, Jason Jablonski ${ }^{1}$, Byars Wells ${ }^{5}$, Daniel H. Fulkerson ${ }^{6}$, Lyndsay Oancea ${ }^{7}$, Abraham Leiser ${ }^{3}$ and Mark Walsh ${ }^{5,8^{*}}$ (D)

\begin{abstract}
Background: The recognition, prevention and treatment of venous thromboembolism (VTE) remains a major challenge in the face of the recent COVID-19 pandemic which has been associated with significant cardiovascular, renal, respiratory and hematologic complications related to hypercoagulability. There has been little literature thus far on the utility of screening ultrasound and the role of the clinical pharmacist in treating these patients.

Methods: We present a prospective pilot program of thirty-one consecutive COVID-19 patients who were provided four extremity screening ultrasounds for VTE on admission. This was coordinated by a clinical pharmacist as part of a multidisciplinary approach. Quantitative and qualitative data were recorded with the goal of describing the utility of the clinical pharmacist in ultrasound screening. Data collected include demographics, information on clinical symptoms or signs at presentation, and laboratory and radiologic results during the hospitalization from each individual electronic medical record.
\end{abstract}

Results: Nine of the thirty-one patients presented with VTE. Of the nine patients, there were twenty-two total clotted vessels, all of which were asymptomatic. The clinical pharmacist, as the coordinator for a multidisciplinary COVID-19 associated coagulopathy management team, drafted a screening and treatment protocol for anticoagulation prophylaxis and therapy of VTE after ultrasound findings.

Conclusion: VTE screening of hospitalized COVID-19 patients reveals a significant number of asymptomatic VTEs and justifies diagnostic, prophylactic, and treatment measures coordinated by a clinical pharmacist.

Keywords: COVID-19, Anticoagulation, Venous thromboembolism, Hypercoagulable, Clinical pharmacist, Ultrasound

\footnotetext{
* Correspondence: markwalshmd@gmail.com

${ }^{5}$ Department of Emergency of Medicine, St. Joseph Regional Medical Center, Mishawaka, IN, USA

${ }^{8}$ Department of Internal Medicine, St. Joseph Regional Medical Center, 5215

Holy Cross Pkwy, Mishawaka, IN 46545, USA

Full list of author information is available at the end of the article
}

C C The Author(s). 2021 Open Access This article is licensed under a Creative Commons Attribution 4.0 International License, which permits use, sharing, adaptation, distribution and reproduction in any medium or format, as long as you give appropriate credit to the original author(s) and the source, provide a link to the Creative Commons licence, and indicate if changes were made. The images or other third party material in this article are included in the article's Creative Commons licence, unless indicated otherwise in a credit line to the material. If material is not included in the article's Creative Commons licence and your intended use is not permitted by statutory regulation or exceeds the permitted use, you will need to obtain permission directly from the copyright holder. To view a copy of this licence, visit http://creativecommons.org/licenses/by/4.0/. The Creative Commons Public Domain Dedication waiver (http://creativecommons.org/publicdomain/zero/1.0/) applies to the data made available in this article, unless otherwise stated in a credit line to the data. 


\section{Background}

Patients hospitalized due to an acute illness have an elevated risk of venous thromboembolism (VTE) while in-hospital and for up to 45 days after hospitalization [1-9]. Patient survival is reduced significantly among patients with VTE, especially after a pulmonary embolism [10]. The risk of VTE in a patient with an acute infectious disease rises up to 32 times that of the general hospitalized patients in some reports $[4,5,11]$. This risk is elevated in patients hospitalized due to COVID-19, yet the level of risk is not clearly defined. Current laboratory parameters--such as prothrombin time/international normalized ratio, partial thromboplastin time, Clauss Fibrinogen, and D-Dimer--lack sensitivity and specificity for predicting VTE in COVID-19 patients [12-17]. We hypothesize that not only severely ill COVID-19 patients in the intensive care unit (ICU) are at risk of VTE, but also that COVID-19 patients hospitalized to the general floor can develop VTE without clinical signs or symptoms.

To date, there is scant literature regarding the screening of extremities for VTE in COVID-19 patients admitted to an ICU [12-17]. Moreover, there is no current consensus regarding the criteria to predict those patients who require standard, high-dose prophylactic, or full anticoagulation treatment. Therefore, it was decided to embark on a program of four extremity screening ultrasound for all patients admitted to the hospital with documented COVID-19. The coordination, collection, and presentation of data was the responsibility of the clinical pharmacist. The template for this multidisciplinary team in addressing anticoagulation was derived from trauma system models. In such models, the clinical pharmacist's duties include medication stewardship in addition to the screening, diagnosis, and monitoring of prophylactic and full anticoagulation treatment [18-21]. Coordinating ultrasound screening under the supervision of a clinician gave the clinical pharmacist an additional tool to help guide them in the management of anticoagulation in COVID-19 patients along with daily D-dimer, fibrinogen and other hematologic markers. The clinical pharmacist would be the first to integrate knowledge of a VTE into their care of patients and therefore they readily took on this additional responsibility. Since the start of the COVID-19 pandemic, experience from China, Europe and the United States has revealed that clinical pharmacists are essential for providing event-driven pharmaceutical care which goes beyond routine activities such as medication review, prescription support, and patient counselling [13, 14, 22-25]. Here, the coordination of four-extremity screening ultrasound for all admitted COVID-19 patients was added to the workload of the clinical pharmacist. In addition, the clinical pharmacist was tasked with assisting in the composition, editing and distribution of off-label anticoagulation protocols for prophylaxis and treatment.
Under the supervision of the clinical pharmacist, thirty-one consecutive patients admitted to the general floor and the ICU were screened with four-extremity ultrasound for VTE. Simultaneously the clinical pharmacist, along with a multidisciplinary team, defined the incidence of VTE in our cohort of COVID-19 patients, evaluated clinical and laboratory risk factors, and developed a treatment protocol. A similar screening and treatment protocol development process, headed by their respective clinical pharmacist, may be adopted by all hospitals to provide comprehensive care for the COVID-19 patient.

\section{Methods}

This study included patients with laboratory-confirmed COVID-19 infection who were admitted between 28 April 2020 and 20 May 2020. Clinical specimens were collected from a nasopharyngeal swab, sputum or bronchial aspirate. Diagnosis of COVID-19 infection was made with the reverse-transcriptase-polymerase-chainreaction assay based on the World Health Organization standard that targets the SARS-CoV-2 E gene and RdRp gene [26]. Thirty-one adults (18 years of age or older) were identified. There were no pregnant women or children admitted to the ICU during the study period. The study protocol was in accordance with the Declaration of Helsinki and approved by the institutional review board of St. Joseph Regional Medical Center Mishawaka. Data collected includes demographics, information on clinical symptoms or signs at presentation, and laboratory and radiologic results during the hospitalization from each individual electronic medical record. All laboratory tests and additional radiologic assessments were performed at the discretion of the attending physician.

A clinical pharmacist was appointed by a multidisciplinary team to coordinate their efforts in identifying and treating COVID-19 patients with VTE. In concert with the infectious disease specialist and hematologist, the clinical pharmacist designed protocols for the ordering of salient laboratory parameters for anticoagulation, as well as criteria for extremity ultrasounds. The clinical pharmacist ordered all ultrasounds of the extremities, initiated and monitored anticoagulation agents, and also assured that all coagulation tests were ordered for each patient according to the defined protocol. Furthermore, the clinical pharmacist, utilizing laboratory and ultrasound findings, made anticoagulant adjustment recommendations.

Upper and lower limb venous compression ultrasound (CUS) was systematically performed in all patients by independent vascular specialists within the first 2 days of admission. The systematic CUS assessed proximal veins. The criterion for establishing the diagnosis of VTE was the lack of compressibility on B-mode ultrasound [27]. 


\section{Results}

Thirty-one patients were screened during the initial phase from 28 April until 20 May 2020. No patient in whom screening ultrasound detected VTE had overt symptoms defined as edema, erythema, or pain. VTE was identified in nine (29\%) patients. All nine (100\%) patients with identifiable VTE were asymptomatic. In these nine patients, a total of twenty-two clotted vessels were diagnosed (See Table 1). There were nine VTEs noted in the extremities. None of these patients had a peripherally inserted central catheter (PICC). None of these patients were receiving anticoagulation prior to COVID-19. Of these nine patients with asymptomatic clots, five were admitted to the ICU and all five were intubated. Demographic analysis of the patients is listed in Table 2.

A protocol for prophylactic and therapeutic anticoagulation was evaluated and revised on a weekly basis by the clinical pharmacist in accordance with guidelines published by the International Society of Hemostasis and Thrombosis. A summary of the current protocol for evaluation and treatment is shown in Fig. 1.

All medication administration was coordinated by the clinical pharmacist. Patients in our study received VTE prophylaxis with daily weight-based subcutaneous enoxaparin or with unfractionated subcutaneous heparin in daily or divided doses. Patients with anatomically proven VTE were treated with weight based subcutaneous enoxaparin, argatroban or with intravenous (IV) unfractionated heparin. Finally, patients admitted to the ICU without anatomic evidence of VTE were treated with either intermediate doses of weight based enoxaparin, argatroban or with therapeutic weight based doses of IV unfractionated heparin.

Table 1 Localization of VTE on CUS

\begin{tabular}{ll}
\hline Anatomic localization of clot & Clots, $\mathbf{N = 2 2}$ \\
\hline Upper extremity & $\mathbf{1 5}(\mathbf{6 8 . 2} \%)$ \\
Axillary & $2(9.1 \%)$ \\
Basillic & $6(27.3 \%)$ \\
Brachial & $3(13.6 \%)$ \\
Cephallic & $4(18.2 \%)$ \\
Lower extremity & $\mathbf{3}(\mathbf{1 3 . 6 \% )}$ \\
Common femoral & $1(4.5 \%)$ \\
Posterior tibial & $2(9.1 \%)$ \\
Other & $\mathbf{4}(\mathbf{1 8 . 2} \%)$ \\
Subclavian & $1(4.5 \%)$ \\
Internal jugular & $1(4.5 \%)$ \\
Common iliac & $1(4.5 \%)$ \\
Scrotal & $1(4.5 \%)$ \\
\hline
\end{tabular}

There were no adverse events that occurred in this group as a result of implementing this program among patients with asymptomatic VTE.

\section{Discussion}

Recent evidence suggests that trauma-induced coagulopathy may be comparable to the hypercoagulable nature of COVID-19 patients [28, 29]. Post-resuscitation trauma patients are at high risk for developing VTE and multiorgan failure due to a shock-induced endotheliopathy and fibrinolytic shutdown. Similar to trauma patients, the mortality and outcome for COVID-19 patients may improve with higher intensity VTE prophylaxis or full anticoagulation to prevent the formation of micro thromboemboli in the pulmonary vasculature [28-42]. COVID-19 coagulopathy, like trauma induced coagulopathy, is characterized by a spectrum of hyper- to hypo-coagulable states in the same patient. Even though our group of patients had no adverse events, hemorrhage as a result of anticoagulation in hospitalized COVID-19 patients was documented. The use of thromboelastography (TEG) for monitoring anticoagulation in hospitalized COVID-19 patients has been shown to be beneficial in guiding changes to anticoagulation for these patients. TEG allows for the clinician to make goal directed anticoagulation decisions on treatment changes which reduces the incidence of hemorrhage [43]. Selection and intensity of anticoagulation in these patients require a dynamic means of evaluation involving screening, prophylaxis, and treatment for VTE $[13,14,44]$. In light of the similar coagulopathies of COVID-19 and trauma patients, it is logical that both patient groups benefit from the expert management of a clinical pharmacist. In our hospital, the clinical pharmacist already coordinated the administration of therapies such as antivirals, convalescent plasma, targeted immunotherapy, and IV antibiotics. The responsibilities of the clinical pharmacist were expanded to include screening and treatment of COVID-19 coagulopathies, including four extremity screening ultrasound for VTE.

Recent data from the NIH ACTIV-4 study demonstrated selective benefit of early anticoagulation for COVID-19 patients. The finding of upper extremity DVTs and/or asymptomatic DVTs would identify higher risk COVID-19 patients in need of anticoagulation early in the admission process. This same trial has demonstrated the potential dangers of delayed anticoagulation in severely ill COVID-19 patients which further increases the importance of early CUS screening and close anticoagulation management of these patients [43, 45]. Nine patients (29\%) who received screening ultrasound were found to have asymptomatic VTE despite no PICC line, one of the strongest risk factors for upper extremity clots. Significantly, this supports the hypercoagulopathic state associated with COVID-19 and the need for an 
Table 2 COVID-19 patient characteristics

\begin{tabular}{|c|c|c|c|}
\hline & Negative VTE $(n=22)$ & Positive for VTE $(n=9)$ & $p$-Value \\
\hline \multicolumn{4}{|l|}{ Demographics } \\
\hline Age (years), mean (SD) & $59.0(17.2)$ & $59.5(14.5)$ & - \\
\hline Female, n (\%) & $7(31.8 \%)$ & $3(33.3 \%)$ & - \\
\hline BMI $\left(\mathrm{kg} / \mathrm{m}^{2}\right)$, mean $(\mathrm{SD})$ & $31.3(9.1)$ & $32.7(9.1)$ & - \\
\hline Prior anticoagulation therapy & $0(0.0 \%)$ & $0(0.0 \%)$ & - \\
\hline \multicolumn{4}{|l|}{ Comorbidities, n (\%) } \\
\hline Hypertension & $11(50.0 \%)$ & $2(22.2 \%)$ & 0.15 \\
\hline Cardiovascular disease & $0(0.00 \%)$ & $4(44.4 \%)$ & 0.0008 \\
\hline COPD & $2(9.09 \%)$ & $3(33.3 \%)$ & 0.10 \\
\hline OSA & $1(4.55 \%)$ & $1(11.1 \%)$ & 0.50 \\
\hline Hepatitis & $0(0.00 \%)$ & $1(11.1 \%)$ & 0.11 \\
\hline Peripheral vascular disease & $1(4.55 \%)$ & $1(11.1 \%)$ & 0.50 \\
\hline Malignancy & $1(4.55 \%)$ & $1(11.1 \%)$ & 0.50 \\
\hline Diabetes & $9(40.9 \%)$ & $1(11.1 \%)$ & 0.10 \\
\hline Renal failure & $1(4.55 \%)$ & $4(44.4 \%)$ & 0.006 \\
\hline Paraplegia & $0(0.00 \%)$ & $1(11.1 \%)$ & 0.11 \\
\hline Singulitis & $0(0.00 \%)$ & $1(11.1 \%)$ & 0.11 \\
\hline \multicolumn{4}{|l|}{ Disposition, n (\%) } \\
\hline ICU & $0(0.00 \%)$ & $5(55.5 \%)$ & 0.0001 \\
\hline Intubation & 0 (0.00\%) & $5(55.5 \%)$ & 0.0001 \\
\hline Death no. & $0(0.00 \%)$ & $1(11.1 \%)$ & 0.11 \\
\hline
\end{tabular}

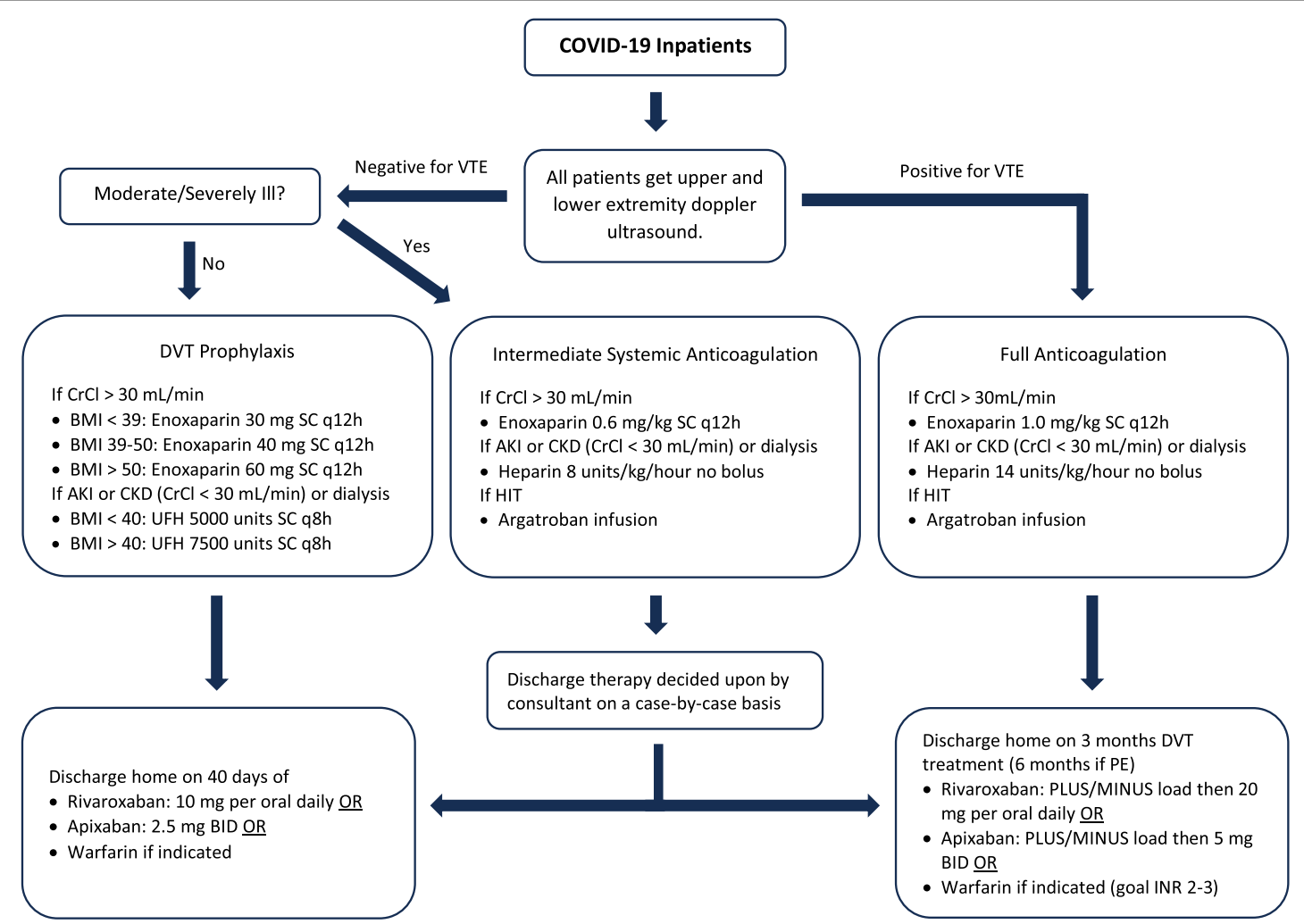

Fig. 1 Saint Joseph Regional Medical Center's Recommended VTE Prophylaxis and Treatment for COVID-19 patients [1, 13, 14] 
evidence-based pharmacologic treatment protocol $[8-10,13,15,16,30,46]$. Recent literature from China, Europe, and the United States has revealed an expanding role for the clinical pharmacist given the evolving nature of guidelines for treating COVID-19 patients [13, 14, 22-25]. Here, the clinical pharmacist drafted guidelines employing ultrasound screening for VTEs to guide anticoagulation therapy; the pharmacist's role is particularly important with increased off-label use of medications during the COVID-19 pandemic.

Patients who screened positive for VTE were found to have high rates of comorbidities including hypertension, cardiovascular disease, chronic obstructive pulmonary disease and renal failure. This points to a potential adverse additive effect of COVID-19 for those with preexisting medical conditions. Among patients with a negative ultrasound screening for VTE, none were admitted to the ICU or intubated (See Table 2). Five of the nine VTE positive patients diagnosed by ultrasound screening were later admitted to the ICU, and each of those five patients were also intubated. A high incidence of VTE in COVID-19 patients admitted to the ICU has recently been reported [17]. Significantly, this demonstrates the importance of having a clinical pharmacist guide screening and therapy for the complex coagulopathy found in COVID-19 patients. With the findings in this study, the authors hope to prompt similar utilization of pharmacists to prevent clotting or bleeding complications in COVID-19 patients.

\section{Conclusions}

We present a pilot experience of a prospective evaluation protocol for COVID-19 associated VTE coordinated by a clinical pharmacist. This clinical pharmacist facilitated COVID-19 patients' ultrasound screening, diagnosis, and monitoring of prophylactic and full anticoagulation treatment [18-21]. This multidisciplinary team was adapted from previous programs that utilized a similar dynamic for management of trauma-related anticoagulation prophylaxis and treatment. Nine of thirty-one (29\%) COVID-19 patients had radiographic evidence of VTE despite no clinical symptoms on initial presentation. These results confirm the recent emphasis on aggressive VTE prophylaxis and treatment due to the relatively high risk of VTE in COVID-19 [13, 14]. Moreover, these results support the importance of having a clinical pharmacist coordinate screening ultrasound for VTE in COVID-19 patients and management of their anticoagulation. This study demonstrates the dynamic and foundational role the clinical pharmacist can play in the management of coagulopathies in the COVID-19 patient.

\section{Abbreviations}

VTE: Venous thromboembolism; ICU: Intensive care unit; CUS: Compression ultrasound; PICC: Peripherally inserted central catheter; IV: Intravenous; TEG: Thromboelastography

\section{Acknowledgements}

David Hofstra, CNMT, R and his team of ultrasound technicians at Saint Joseph Regional Medical Center

Hamid Al-Fadhl, Anthony V. Thomas and Grant Wiarda for data curation, entry and statistics.

\section{Authors' contributions \\ LG, RK, FS, JS, AG, MWS, HP, JJ, BW, LO, MW contributed to the collection and interpretation of data. JES, CB, RK, MW, FS, JS, RK, MW contributed to the literature review. $L G, R K, J E S, C B, F S, J S, M W$ contributed to writing the paper. All authors contributed to critical review and revision of the paper. The author(s) read and approved the final manuscript.}

\section{Funding}

No funding to declare

\section{Availability of data and materials}

The datasets used and/or analysed during the current study are available from the corresponding author on reasonable request.

\section{Declarations}

\section{Ethics approval and consent to participate}

The study protocol was in accordance with the Declaration of Helsinki, and approved by institutional review board of Saint Joseph Regional Medical Center Mishawaka (2020-00856).

\section{Consent for publication}

Not applicable

\section{Competing interests}

MW receives research grants from Haemonetics Incorporated, Boston, MA and is on the speaker's bureau for Portola Incorporated San Francisco, CA. All other authors have no conflicts to report.

\section{Author details}

'Department of Quality and Performance Improvement, Saint Joseph Regional Medical Center, Mishawaka, IN, USA. ${ }^{2}$ Department of Hematology, Michiana Hematology Oncology, Mishawaka, IN, USA. ${ }^{3}$ South Bend Campus, Indiana University School of Medicine, South Bend, IN, USA. ${ }^{4}$ Department of Infectious Diseases, St. Joseph Regional Medical Center, Mishawaka, IN, USA. ${ }^{5}$ Department of Emergency of Medicine, St. Joseph Regional Medical Center, Mishawaka, IN, USA. 'Department of Neurosurgery, St. Joseph Regional Medical Center, Mishawaka, IN, USA. ${ }^{7}$ Department of Radiology, St. Joseph Regional Medical Center, Mishawaka, IN, USA. ${ }^{8}$ Department of Internal Medicine, St. Joseph Regional Medical Center, 5215 Holy Cross Pkwy, Mishawaka, IN 46545, USA.

Received: 8 November 2020 Accepted: 10 March 2021

Published online: 01 April 2021

\section{References}

1. Spyropoulos AC, Anderson FA Jr, FitzGerald G, et al. Predictive and associative models to identify hospitalized medical patients at risk for VTE. Chest. 2011;140(3):706-14. https://doi.org/10.1378/chest.10-1944.

2. Amin AN, Varker H, Princic N, Lin J, Thompson S, Johnston S. Duration of venous thromboembolism risk across a continuum in medically ill hospitalized patients. J Hosp Med. 2012;7(3):231-8. https://doi.org/10.1002/ jhm.1002.

3. Cohoon KP, Ashrani AA, Crusan DJ, Petterson TM, Bailey KR, Heit JA. Is infection an independent risk factor for venous thromboembolism? A population-based, case-control study. Am J Med. 2018;131:307-16.e2.

4. Smeeth L, Cook C, Thomas S, Hall AJ, Hubbard R, Vallance P. Risk of deep vein thrombosis and pulmonary embolism after acute infection in a community setting. Lancet. 2006;367(9516):1075-9. https://doi.org/10.1016/ S0140-6736(06)68474-2.

5. Schmidt M, Horvath-Puho E, Thomsen RW, Smeeth L, Sørensen HT. Acute infections and venous thromboembolism. J Intern Med. 2012;271(6):608-18. https://doi.org/10.1111/j.1365-2796.2011.02473.X.

6. Konstantinides SV, Meyer G, Becattini C, Bueno H, Geersing GJ, Harjola VP, Huisman MV, Humbert M, Jennings CS, Jiménez D, Kucher N, Lang IM, 
Lankeit M, Lorusso R, Mazzolai L, Meneveau N, Ní Áinle F, Prandoni P, Pruszczyk P, Righini M, Torbicki A, van Belle E, Zamorano JL, ESC Scientific Document Group, Galié N, Gibbs JSR, Aboyans V, Ageno W, Agewall S, Almeida AG, Andreotti F, Barbato E, Bauersachs J, Baumbach A, Beygui F, Carlsen J, de Carlo M, Delcroix M, Delgado V, Subias PE, Fitzsimons D, Gaine S, Goldhaber SZ, Gopalan D, Habib G, Halvorsen S, Jenkins D, Katus HA, Kjellström B, Lainscak M, Lancellotti P, Lee G, le Gal G, Messas E, Morais J, Petersen SE, Petronio AS, Piepoli MF, Price S, Roffi M, Salvi A, Sanchez O, Shlyakhto E, Simpson IA, Stortecky S, Thielmann M, Noordegraaf AV, Becattini C, Bueno H, Geersing GJ, Harjola VP, Huisman MV, Humbert M, Jennings CS, Jiménez D, Kucher N, Lang IM, Lankeit M, Lorusso R, Mazzola L, Meneveau N, Ní Áinle F, Prandoni P, Pruszczyk P, Righini M, Torbicki A, VanBelle E, LuisZamorano J, Windecker S, Aboyans V, Baigent C, Collet JP, Dean V, Delgado V, Fitzsimons D, Gale CP, Grobbee D, Halvorsen S, Hindricks $G$, lung $B$, Jüni $P$, Katus HA, Landmesser $U$, Leclerca $C$, Lettino $M$, Lewis BS, Merkely B, Mueller C, Petersen SE, Sonia Petronio A, Richter DJ, Roffi M, Shlyakhto E, Simpson IA, Sousa-Uva M, Touyz RM, Hammoudi N, Hayrapetyan H, Mascherbauer J, Ibrahimov F, Polonetsky O, Lancellotti P, Tokmakova M, Skoric B, Michaloliakos I, Hutyra M, Mellemkjaer S, Mostafa M, Reinmets J, Jääskeläinen P, Angoulvant D, Bauersachs J, Giannakoulas G, Zima E, Vizza CD, Sugraliyev A, Bytyçi I, Maca A, Ereminiene E, Huijnen S, Xuereb R, Diaconu N, Bulatovic N, Asfalou I, Bosevski M, Halvorsen S, Sobkowicz B, Ferreira D, Petris AO, Moiseeva O, Zavatta M, Obradovic S, Šimkova I, Radsel P, Ibanez B, Wikström G, Aujesky D, Kaymaz C, Parkhomenko A, Pepke-Zaba J. 2019 ESC guidelines for the diagnosis and management of acute pulmonary embolism developed in collaboration with the European Respiratory Society (ERS). Eur Heart J. 2020;41(4):543-603. https://doi.org/10.1093/eurhearti/ehz405.

7. Wang L, Sengupta N, Baser O. Risk of venous thromboembolism and benefits of prophylaxis use in hospitalized medically ill US patients up to 180 days post-hospital discharge. Thromb J. 2011;9(1):15. https://doi.org/1 0.1186/1477-9560-9-15.

8. Danzi GB, Loffi M, Galeazzi G, Gherbesi E. Acute pulmonary embolism and COVID-19 pneumonia: a random association? Eur Heart J. 2020;41(19):1858. https://doi.org/10.1093/eurhearti/ehaa254.

9. Xie $Y$, Wang $X$, Yang P, Zhang S. COVID-19 complicated by acute pulmonary embolism. Radiol Cardiothorac Imaging. 2020;2(2):e200067. https://doi.org/1 0.1148/ryct.2020200067.

10. Heit JA, Silverstein MD, Mohr DN, Petterson TM, O'Fallon WM, Melton LJ. Predictors of survival after deep vein thrombosis and pulmonary embolism: a population-based, cohort study. Arch Intern Med. 1999;159(5):445-53. https://doi.org/10.1001/archinte.159.5.445.

11. Rogers MA, Levine DA, Blumberg N, Flanders SA, Chopra V, Langa KM. Triggers of hospitalization for venous thromboembolism. Circulation. 2012; 125(17):2092-9. https://doi.org/10.1161/CIRCULATIONAHA.111.084467.

12. Longchamp A, Longchamp J, Manzocchi-Besson S, Whiting L, Haller C, Jeanneret S, Godio M, Garcia Martinez JJ, Bonjour T, Caillat M, Maitre G, Thaler JM, Pantet R, Donner V, Dumoulin A, Emonet S, Greub G, Friolet R, Robert-Ebadi H, Righini M, Sanchez B, Delaloye J. Venous thromboembolism in critically ill patients with COVID-19: results of a screening study for deep vein thrombosis. Res Pract Thromb Haemost. 2020;4(5):842-7. https://doi. org/10.1002/rth2.12376.

13. Cohoon KP, Mahé G, Tafur AJ, Spyropoulos AC. Emergence of institutional antithrombotic protocols for coronavirus 2019. Res Pract Thromb Haemost. 2020;4(4):510-7.

14. Thachil J, Tang N, Gando S, Falanga A, Cattaneo M, Levi M, Clark C, Iba T. ISTH interim guidance on recognition and management of coagulopathy in COVID19. J Thromb Haemost. 2020;18(5):1023-6. https://doi.org/10.1111/jth.14810.

15. Zhou F, Yu T, Du R, et al. Clinical course and risk factors for mortality of adult inpatients with COVID-19 in Wuhan, China: a retrospective cohort study. Lancet. 2020;395(10229):1054-62. https://doi.org/10.1016/S0140-673 6(20)30566-3.

16. Panigada M, Bottino N, Tagliabue P, et al. Hypercoagulability of COVID-19 patients in intensive care unit. A report of thromboelastography findings and other parameters of hemostasis. J Thromb Haemost. 2020;18(7):1738-42.

17. Llitjos JF, Leclerc M, Chochois C, Monsallier JM, Ramakers M, Auvray M, Merouani K. High incidence of venous thromboembolic events in anticoagulated severe COVID-19 patients. J Thromb Haemost. 2020;18(7): 1743-6. https://doi.org/10.1111/jth.14869.

18. Anderegg SV, DeMik DE, Carter BL, et al. Acceptance of recommendations by inpatient pharmacy case managers: unintended consequences of hospitalist and specialist care. Pharmacotherapy. 2013;33(1):11-21. https:// doi.org/10.1002/phar.1164.

19. Scrimenti A, Seabury RW, Miller CD, et al. Pharmacist recommendations for prophylactic enoxaparin monitoring and dose adjustment in trauma patients admitted to a surgical intensive care unit. Pharm Pract. 2019;17:1541.

20. Devlin JW, Tyburski JG, Moed B. Implementation and evaluation of guidelines for use of enoxaparin as deep vein thrombosis prophylaxis after major trauma. Pharmacotherapy. 2001;21(6):740-7. https://doi.org/10.1592/ phco.21.7.740.34578.

21. Walker CK, Sandmann EA, Horyna TJ, Gales MA. Increased enoxaparin dosing for venous thromboembolism prophylaxis in general trauma patients. Ann Pharmacother. 2017;51(4):323-31. https://doi.org/10.1177/1 060028016683970

22. Cadogan CA, Hughes CM. On the frontline against COVID-19: community pharmacists' contribution during a public health crisis. Res Soc Adm Pharm. 2020;17(1):2032-5.

23. Li H, Zheng S, Liu F, Liu W, Zhao R. Fighting against COVID-19: innovative strategies for clinical pharmacists. Res Soc Adm Pharm. 2020;17(1):1813-8.

24. Liu S, Luo P, Tang M, Hu Q, Polidoro JP, Sun S, Gong Z. Providing pharmacy services during the coronavirus pandemic. Int J Clin Pharm. 2020;42(2):299304. https://doi.org/10.1007/s11096-020-01017-0.

25. Zheng S-Q, Yang L, Zhou P-X, Li H-B, Liu F, Zhao R-S. Recommendations and guidance for providing pharmaceutical care services during COVID-19 pandemic: a China perspective. Res Soc Adm Pharm. 2020;17(1):1819-24.

26. Corman VM, Landt O, Kaiser M, et al. Detection of 2019 novel coronavirus (2019-nCoV) by real-time RT-PCR. Eurosurveillance. 2020;25:2000045.

27. Lensing AW, Prandoni P, Brandjes D, et al. Detection of deep-vein thrombosis by real-time B-mode ultrasonography. New Engl J Med. 1989; 320(6):342-5. https://doi.org/10.1056/NEJM198902093200602.

28. Moore HB, Moore EE, Neal MD, Sheppard FR, Kornblith LZ, Draxler DF, Walsh M, Medcalf RL, Cohen MJ, Cotton BA, Thomas SG, Leeper CM, Gaines BA, Sauaia A. Fibrinolysis shutdown in trauma: historical review and clinical implications. Anesth Analg. 2019;129(3):762-73. https://doi.org/10.1213/ANE. 0000000000004234.

29. Meizoso JP, Karcutskie CA, Ray JJ, Namias N, Schulman Cl, Proctor KG. Persistent fibrinolysis shutdown is associated with increased mortality in severely injured trauma patients. J Am Coll Surg. 2017;224(4):575-82. https:// doi.org/10.1016/j.jamcollsurg.2016.12.018.

30. Moore HB, Barrett CD, Moore EE, et al. Is there a role for tissue plasminogen activator as a novel treatment for refractory COVID-19 associated acute respiratory distress syndrome? J Trauma Acute Care. 2020;88(6):1.

31. Brill JB, Badiee J, Zander AL, Wallace JD, Lewis PR, Sise MJ, Bansal V, Shackford SR. The rate of deep vein thrombosis doubles in trauma patients with hypercoagulable thromboelastography. J Trauma Acute Care. 2017; 83(3):413-9. https://doi.org/10.1097/TA.0000000000001618.

32. Coleman JR, Kay AB, Moore EE, Moore HB, Gonzalez E, Majercik S, Cohen MJ, White T, Pieracci FM. It's sooner than you think: blunt solid organ injury patients are already hypercoagulable upon hospital admission-results of a bi-institutional, prospective study. Am J Surg. 2019;218(6):1065-73. https:/ doi.org/10.1016/j.amjsurg.2019.08.024

33. Cotton BA, Minei KM, Radwan ZA, Matijevic N, Pivalizza E, Podbielski J, Wade CE, Kozar RA, Holcomb JB. Admission rapid thrombelastography predicts development of pulmonary embolism in trauma patients. J Trauma Acute Care. 2012;72(6):1470-7. https://doi.org/10.1097/TA.0b013e31824d56ad.

34. McCrath DJ, Cerboni E, Frumento RJ, Hirsh AL, Bennett-Guerrero E. Thromboelastography maximum amplitude predicts postoperative thrombotic complications including myocardial infarction. Anesth Analg. 2005;100(6):1576-83. https://doi.org/10.1213/01.ANE.0000155290.86795.12.

35. Harahsheh Y, Duff OC, Ho KM. Thromboelastography predicts thromboembolism in critically ill coagulopathic patients. Crit Care Med. 2019:47(6):826-32. https://doi.org/10.1097/CCM.0000000000003730.

36. Myers SP, Kutcher ME, Rosengart MR, Sperry JL, Peitzman AB, Brown JB, Neal MD. Tranexamic acid administration is associated with an increased risk of posttraumatic venous thromboembolism. J Trauma Acute Care. 2019;86(1): 20-7. https://doi.org/10.1097/TA.0000000000002061.

37. Moore H, Moore E, Gonzalez E, et al. Hyperfibrinolysis, physiologic fibrinolysis, and fibrinolysis shutdown: the spectrum of postinjury fibrinolysis and relevance to antifibrinolytic therapy. J Trauma Acute Care. 2014;77(6): 811-7; Discussion 7. https://doi.org/10.1097/TA.0000000000000341.

38. Moore HB, Moore EE, Liras IN, Gonzalez E, Harvin JA, Holcomb JB, Sauaia A, Cotton BA. Acute fibrinolysis shutdown after injury occurs frequently and 
increases mortality: a multicenter evaluation of 2,540 severely injured patients. J Am Coll Surg. 2016;222(4):347-55. https://doi.org/10.1016/j.ja mcollsurg.2016.01.006.

39. Leeper CM, Neal MD, McKenna CJ, Gaines BA. Trending fibrinolytic dysregulation: fibrinolysis shutdown in the days after injury is associated with poor outcome in severely injured children. Ann Surg. 2017;266(3):50815. https://doi.org/10.1097/SLA.0000000000002355.

40. Roberts DJ, Kalkwarf KJ, Moore HB, Cohen MJ, Fox EE, Wade CE, Cotton BA. Time course and outcomes associated with transient versus persistent fibrinolytic phenotypes after injury: a nested, prospective, multicenter cohort study. J Trauma Acute Care. 2019;86(2):206-13. https://doi.org/10.1 097/TA.0000000000002099

41. Hardaway RM, Harke $\mathrm{H}$, Tyroch AH, Williams CH, Vazquez Y, Krause GF. Treatment of severe acute respiratory distress syndrome: a final report on a phase I study. Am Surg. 2001:67(4):377-82.

42. Wang J, Hajizadeh N, Moore EE, McIntyre RC, Moore PK, Veress LA, Yaffe MB, Moore HB, Barrett CD. Tissue plasminogen activator (tPA) treatment for COVID-19 associated acute respiratory distress syndrome (ARDS): a case series. J Thromb Haemost. 2020;18(7):1752-5. https://doi. org/10.1111/jth. 14828

43. Stillson JE, Bunch CM, Gillespie $L$, et al. Thromboelastography-guided management of anticoagulated COVID-19 patients to prevent hemorrhage. Semin Thromb Hemost. 2021. https://doi.org/10.1055/s-0041-1723754.

44. Wright $\mathrm{FL}$, Vogler TO, Moore $\mathrm{EE}$, et al. Fibrinolysis shutdown correlates to thromboembolic events in severe COVID-19 infection. J Am Coll Surg. 2020; 231(2):193-203.e1. https://doi.org/10.1016/j.jamcollsurg.2020.05.007.

45. National Institutes of Health. Full-dose blood thinners decreased need for life support and improved outcome in hospitalized COVID-19 patients [Internet]: U.S. Department of Health and Human Services; 2021. [Updated 2021 Jan 22; cited 2021 Jan 23]. Available from: https://www.nih.gov/newsevents/news-releases/full-dose-blood-thinners-decreased-need-life-supportimproved-outcome-hospitalized-covid-19-patients

46. Yao XH, Li TY, He ZC, Ping YF, Liu HW, Yu SC, Mou HM, Wang LH, Zhang HR, Fu WJ, Luo T, Liu F, Guo QN, Chen C, Xiao HL, Guo HT, Lin S, Xiang DF, Shi Y, Pan GQ, Li QR, Huang X, Cui Y, Liu XZ, Tang W, Pan PF, Huang XQ, Ding YQ, Bian XW. A pathological report of three COVID-19 cases by minimal invasive autopsies. Zhonghua Bing Li Xue Za Zhi. 2020;49(5):411-7. https://doi.org/10.3760/cma.j.cn112151-20200312-00193.

\section{Publisher's Note}

Springer Nature remains neutral with regard to jurisdictional claims in published maps and institutional affiliations.

Ready to submit your research? Choose BMC and benefit from:

- fast, convenient online submission

- thorough peer review by experienced researchers in your field

- rapid publication on acceptance

- support for research data, including large and complex data types

- gold Open Access which fosters wider collaboration and increased citations

- maximum visibility for your research: over $100 \mathrm{M}$ website views per year

At $\mathrm{BMC}$, research is always in progress.

Learn more biomedcentral.com/submissions 